\title{
Daytime concentrations of minor and trace elements in atmospheric aerosols at four sampling sites of Dar es Salaam, Tanzania
}

\author{
Albert Geoffrey Mmari ${ }^{1}$ - Hassan Ali Hassan ${ }^{2}$ • László Bencs ${ }^{3}$ (D) \\ Received: 15 January 2020 / Accepted: 28 April 2020 /Published online: 15 May 2020 \\ (C) The Author(s) 2020
}

\begin{abstract}
Tropospheric aerosols (total suspended particulate, TSP) were sampled at four sampling sites of various anthropogenic impact (industrial, commercial, heavy trafficked, and mixed urban influence), located in Dar es Salaam, the commercial capital of Tanzania. Air concentrations of minor and trace elements (Al, As, Br, Ca, Cd, Cl, Cr, Cu, Fe, K, Mg, Mn, Na, Ni, Pb, S, Si, $\mathrm{Sb}$, and $\mathrm{Zn}$ ) in TSP were determined by means of wavelength-dispersive X-ray fluorescence (WDXRF) spectrometry and inductively coupled plasma atomic emission spectrometry (ICP-AES). From these data, the main ionic composition of particulate matter was inferred by means of a species correlation/ratio-derived approach, based on former studies of the region. Enrichment factors, bivariate correlations, diagnostic ratios, and chemical mass closures were calculated utilizing the concentration data of TSP constituents for each site in order to reveal the emission sources. A couple of diagnostic $\operatorname{ratios}(\mathrm{Ni} / \mathrm{Cd}, \mathrm{Zn} / \mathrm{Cd}, \mathrm{Br} / \mathrm{Ni}, \mathrm{Ni} / \mathrm{Sb})$ were useful for source identification, e.g., motor vehicle exhaust and non-exhaust emissions. Significant increases in concentrations of $\mathrm{As}, \mathrm{Br}, \mathrm{Cr}, \mathrm{Cu}, \mathrm{Mn}, \mathrm{Ni}, \mathrm{Pb}$, and $\mathrm{Zn}$ were observed, as compared to results for the city before 2010 . Moreover, first-time air levels are reported for $\mathrm{Cd}$ and $\mathrm{Sb}$, which are important markers of non-exhaust emissions. Air quality indices and calculations with the $\mathrm{AIRQ}^{+}$model have foreseen increases in the negative health effects of the sensitive groups of the local population at the study areas, especially those with heavy traffic, industrial, and/or mixed urban influence.
\end{abstract}

Keywords Toxic element content $\cdot$ Heavy metals · Aerosol mineral content $\cdot$ Non-exhaust emission · Source apportionment . Chemical mass closure

\section{Introduction}

Particulate matter (PM) suspended in Earth's atmosphere affects the air quality of densely populated areas, thus the health of the human population and the wild and domestic animals (Seinfeld and Pandis 2016). Airborne PM plays a decisive role in global climate change in a direct and an indirect way

Electronic supplementary material The online version of this article (https://doi.org/10.1007/s11869-020-00832-8) contains supplementary material, which is available to authorized users.

László Bencs

bencs.laszlo@wigner.mta.hu

1 Department of Science and Laboratory Technology, Dar es Salaam Institute of Technology (DIT), P.O. Box 2958,

Dar es Salaam, Tanzania

2 Department of Physics, University of Dar es Salaam, P.O. Box 35063, Dar es Salaam, Tanzania

3 Institute for Solid State Physics and Optics, Wigner Research Centre for Physics, Hungarian Academy of Sciences, P.O. Box 49, Budapest H-1525, Hungary
(Seinfeld and Pandis 2016; IPCC 2007). Consequently, there is a certain quest in the scientific aerosol community for acquiring sharper knowledge on the exact chemical composition of tropospheric aerosols, in order to attain more accurate characterization of their sources, sinks and transport in the air on regional and global scales (Maenhaut 2008).

The literature often reports on chemistry and compositions of atmospheric aerosols for European, Asian, and American sites in densely populated areas with varying industrial densities and traffic frequencies, as well as rural/agricultural/countryside locations. In contrast, air pollution studies from the large African continent are much scarcer, according to literature reviews (Petkova et al. 2013; Fayiga et al. 2018). For instance, air quality studies have been reported from Cameroon (Adiang et al. 2017), Egypt (Favez et al. 2008), equatorial eastern Africa (Gatebe et al. 2001), Kenya (Kinney et al. 2011), South Africa (Maenhaut et al. 1996), Nigeria (Baumbach et al. 1995; Owoade et al. 2015; Alani et al. 2019), Zimbabwe (Nyanganyura et al. 2007), and Tanzania (Mbuligwe and Kassenga 1997; Koleleni 1998; Koleleni 2003; Jonsson et al. 2004; Bennet et al. 2005; Mkoma 2008; Mkoma et al. 2009a, 2009b; Mmari et al. 2013; 
Ndetto and Matzarakis 2015). Most of these studies were focusing on bulk elemental content, water-soluble ionic components, aerosol mass closures, and/or daily/seasonal changes. Other studies went deep into the identification of emission sources on the basis of compositional analysis of single air particulates (Pósfai et al. 2003; Li et al. 2003) or the atmospheric transport of aerosols through the continent (Piketh et al. 2002). By taking into account the rising anthropogenic burden of the rapidly growing industrial and urban environments of large African cities, it is necessary to revisit from time to time the elemental aerosol composition, as well as to make an estimate on the chemical composition and related air quality parameters to get a sharper insight into temporal trends of toxic components in the ambient air of industrialized and densely populated areas. This would give a clue towards likely effects of the rising atmospheric pollution burden on local population, in terms of intake, deposition, and bioaccumulation of air toxics.

It is apparent from the above literature survey that African aerosol studies often lack the data on exact chemical composition regarding minor and trace components, closely related to certain health effects of the local population. For the assessment of these aerosol species, besides the application of proper statistical and modelling methods, analytical techniques of high sensitivity and selectivity are required. Inductively coupled plasma atomic emission spectrometry (ICP-AES) is a frequently applied technique for the determination of the elemental content in atmospheric aerosols, though studies from Africa have only been reported in a few cases (Niyobuhungiro and von Blottnitz 2013; Bencharif-Madani et al. 2019), while wavelength-dispersive X-ray fluorescence (WDXRF) spectrometry is less often applied in atmospheric aerosol studies in general (e.g., Talebi 1998; Remoundaki et al. 2013; Pekey et al. 2015; Zhang et al. 2018).

In the present study, filter sampling combined with WDXRF and ICP-AES analysis is applied for monitoring the elemental content of total suspended particulate (TSP) in the air of four sampling sites of different anthropogenic influence in Dar es Salaam city, Tanzania. Likewise, various chemical model calculations and statistical methods are applied to the acquired air concentration data, in order to approach the elemental composition of the sampled urban aerosols in a more realistic way. Additionally, calculations have been performed to predict the health effects of the local population on the basis of the observed daily atmospheric aerosol concentration.

\section{Experimental}

\section{Description of the sampling sites}

Dar es Salaam, the commercial capital of Tanzania, is located in the Sub-Saharan East Africa along the coast of the Indian Ocean. The city lies on an area of $1350 \mathrm{~km}^{2}$ between latitudes of $3.36^{\circ}$ and $7.00^{\circ} \mathrm{S}$ and longitudes of $33.3^{\circ}$ and $39.0^{\circ} \mathrm{E}$. With a population of over 4.7 million in 2016, it is the third largest city of Africa. Its motor vehicle fleet experienced a steep growth of 15-20\% per year between $2005(319,200$ registered vehicles) and 2014 (over 1.5 million vehicles). The road network of Dar es Salaam is approximately $1950 \mathrm{~km}$ long, of which $1120 \mathrm{~km}$ is paved. Most of these roads are of poor surface conditions and generally overcrowded with people and gasoline- and diesel-fuelled heavy- and light-duty vehicles, particularly during daytime. The daily traffic is peaking between 6 a.m. and 9 a.m. and between 4 p.m. and 8 p.m., with frequent traffic jams.

The first study site is the Ubungo bus terminal, located at the junction of two busy trafficked roads of Morogoro and Sam Nujoma, where the dense traffic of heavy and light vehicles often causes traffic jams. The sampling site is also with industrial factories of Ubungo Farm Implements, Friendship textile (Urafiki), Chibuku brewery, and, additionally, a large diesel- and gas-generating power plant (TANESCO). The second sampling site, Kariakoo, is situated at a commercial area, which includes the main food market of Tanzania, thus with high traffic congestion of heavy- and light-duty transport vehicles. This site also incorporates shops, breweries, garages, and metallic workshops. Moreover, there are new building constructions and renovation of old buildings, e.g., shops, hotels, and residential buildings. The third sampling location (Jangwani) is at the junction of the United Nations and the Morogoro road. At this site, the vehicular traffic was relatively slow, due to continuous traffic jams along the Morogoro road, which was under construction during the sampling campaign. Moreover, the site is characterized with small enterprises and garages. Near the site, two large powered diesel generators are installed in towers of Airtel and Tigo, which are utilized for electricity production to bypass droughty periods. Hence, this sampling site can rather be described as with mixed anthropogenic influence. The fourth sampling site (Chang'ombe) is an industrial area, which is located $7 \mathrm{~km}$ west of the Morogoro road. This area consists of numerous production and manufacturing industries, such as Serengeti brewery, Gold Star Paints, printing services, furniture and cello, and glass and aluminum factories. Moreover, there are dusty roads with quite dense traffic of heavy trucks and other smaller types of transport motor vehicles. The map of the region with the denoted sampling sites is depicted on Fig. 1.

\section{Apparatus}

\section{Sampling campaigns and techniques}

Atmospheric TSP at a height of 2-2.5 $\mathrm{m}$ from the ground level was collected for $6 \mathrm{~h}$ per day from 9 a.m. until 3 p.m. in the dry season (weekends not included) in 2014, i.e., June 16-27, June 30-July 11, July 14-25, and August 4-15, for 


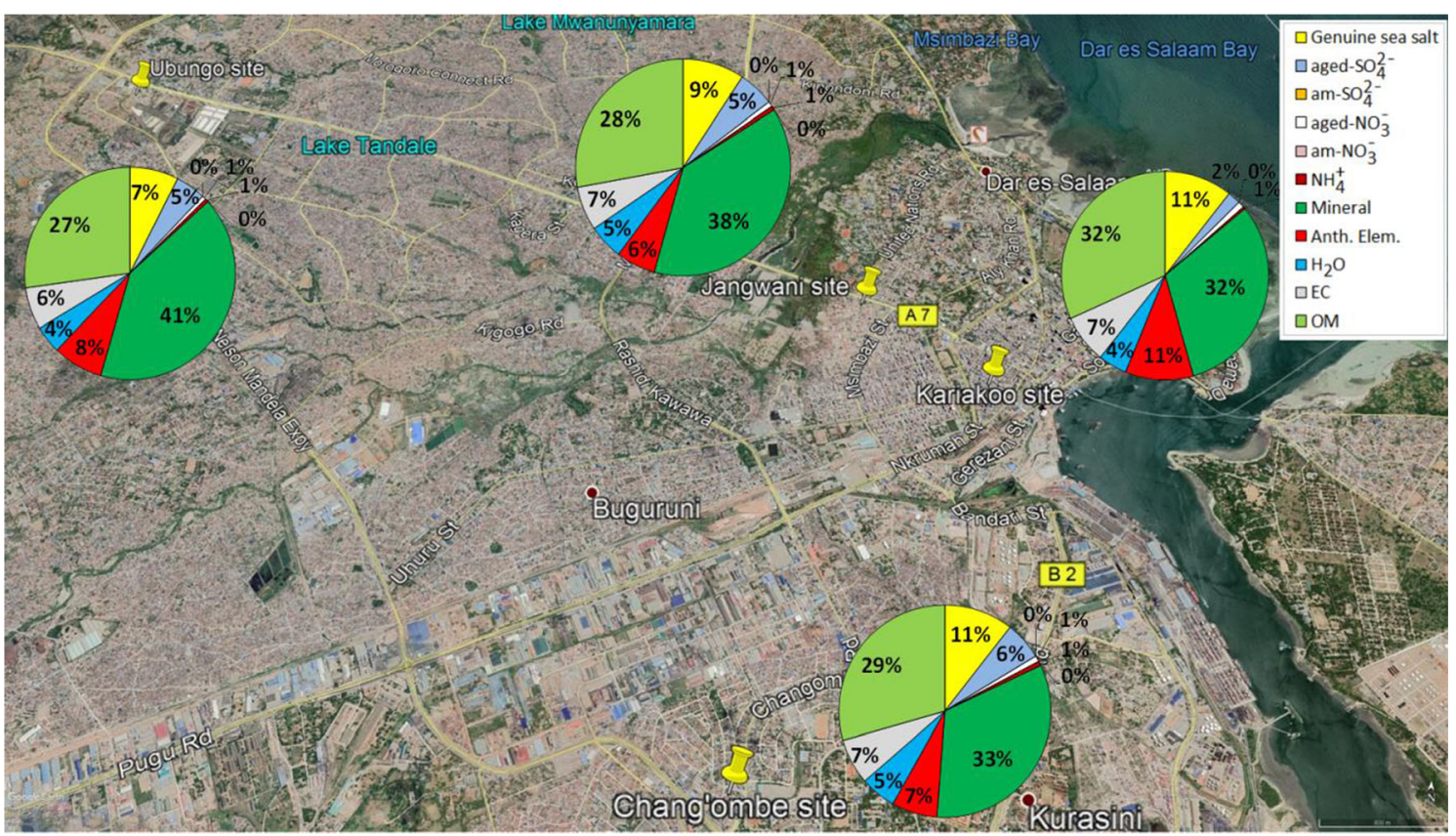

Fig. 1 Map of the study region in the city of Dar es Salaam (Source: Google Earth) with the denoted four sampling sites (Kariakoo, Jangwani, Chang'ombe, and Ubungo) and the relative average contributions of various aerosol components to TSP during the sampling campaigns

Kariakoo, Jangwani, Chang'ombe, and Ubungo, respectively. For air sampling, a stacked filter unit (SFU) was connected to a model VT4.4 vacuum pump (Gebr. Becker GmbH, Wuppertal, Germany) and a Gallus-2000 gas-flow meter through flexible plastic tubing, operated at an air flow rate of $16.7 \mathrm{dm}^{3} / \mathrm{min}$. For each sampling cycle, the SFU was supplied with a Nuclepore ${ }^{\mathrm{TM}}$ track-etched polycarbonate membrane filter of $0.2-\mu \mathrm{m}$ porosity and $47-\mathrm{mm}$ diameter, used as a host surface for aerosol collection. Beneath this, a Whatman ${ }^{\circledR}$ QM-A quartz filter of the same diameter was applied to provide a mechanical support for it and to assure uniform distribution of the particles on its surface. Each filter was kept in a closed Petri slide dish. After sampling, they were stored in a fridge at $4{ }^{\circ} \mathrm{C}$ until sample processing. Meteorological data were acquired from local weather stations. The monthly/ seasonal weather data are compiled in Table S1 (vid. Supplementary File), while the trends of average daily data are visualized in Fig. S1.

\section{WDXRF and ICP-AES analysis}

For WDXRF analyses, a Bruker Model S8 TIGER Series-2 spectrometer was applied equipped with a ten-position beam filter changer and a Quant-Express and SPECTRA ${ }^{\text {plus }}$ Software. The X-ray tube of this equipment is with an $\mathrm{Rh}$ target and a Be window of 28- $\mu \mathrm{m}$ thickness, which can be operated maximally at a power of $4 \mathrm{~kW}$, a current of $170 \mathrm{~mA}$, and an acceleration voltage of $60 \mathrm{kV}$. A scintillation and a proportional counter was applied for the detection of heavy $(Z>25)$ and light $(Z<26)$ elements, respectively. The adjustment of collimators, analyzer crystals, and detectors was optimized to attain high resolution and sensitivity. The Quant-Express provides a powerful correction method for matrix effects, thus a proper tool for the automatic calibration/ analysis of unknown samples. For quality assurance, singleelement thin film standards and a certified standard reference material (CRM) of NIST-2783 (air particulate on filter media) were applied. The measured concentrations of the analytes in the CRM were in the range of $6-14 \%$ as compared with the certified data. The minimum detection limit (MDL) for aerosol filters was calculated using the expression found elsewhere (Van Grieken and Markowicz 2001) and listed in Table S2.

For the ICP-AES analysis, a Jobin-Yvon Model Ultima-2 spectrometer equipped with a concentric glass nebulizer and an AS-500 autosampler was applied. Rinsing, stabilization, and transfer time was optimally set at 5,10 , and $25 \mathrm{~s}$, respectively. The argon plasma was radially observed, which provided the method with negligible matrix interferences. Average concentration, median, and standard deviation (SD) values were calculated from triplicate runs. For the determination of trace elements ( $\mathrm{As}, \mathrm{Cd}, \mathrm{Cr}, \mathrm{Ni}, \mathrm{Pb}, \mathrm{Zn}$ ) and minor elements (Ca, K, Mg, Na, P, S) in TSP, the acquisition mode (narrow slit: $20 \times 15 \mu \mathrm{m}$, with higher resolution and sensitivity) and the maximum mode (wide slit: $20 \times 80 \mu \mathrm{m}$ ) were applied, respectively. Five calibration solutions were applied in the range of $0.1-10 \mathrm{mg} / \mathrm{L}$ for each analyte, diluted from Merck certified standards (Darmstadt, Germany). Calculated MDL values for the ICP-AES analysis are compiled in Table S3. The accuracy of the ICP-AES results was assessed by the analysis of a CRM, TILL-2 Geochemical Soil (Natural Resources Canada, CANMET Mining, Ottawa, Ontario, Canada) (see Table S4). 


\section{Materials and reagents}

For WDXRF determinations, aerosol loaded and blank filters were analyzed without any sample pretreatment. For ICPAES analysis, the sample filters were weighed on an OHAUS Model PR124 (Nänikon, Switzerland) electronic balance. Each filter was digested in a borosilicate test tube with $5 \mathrm{~mL}$ of freshly prepared aqua regia. Before it, the filter was cut into two pieces, and one of them was digested in open air, at $100{ }^{\circ} \mathrm{C}$ for $8 \mathrm{~h}$, using a Model Biometra TB2 thermoblock (Analytik Jena AG, Germany). For the analysis of $\mathrm{Br}, \mathrm{Hg}$, and $\mathrm{Pb}$, the second sample pieces were heated gently to $65{ }^{\circ} \mathrm{C}$. After digestion, the sample solutions were cooled to room temperature, and then $10 \mathrm{~mL}$ of high-purity Milli-Q water (Millipore, Billerica, USA) was added to each, thereafter, they were filtered and stored in sealed volumetric flasks in a fridge at $4{ }^{\circ} \mathrm{C}$ until analysis. Each sample solution was diluted with high-purity water up to a final volume of $15 \mathrm{~mL}$ prior to analysis.

\section{Statistical evaluation and model methods}

Multivariate statistical analysis was performed by application of the SPSS software (versions 16-20). The distribution of the air concentration data was determined with the Shapiro-Wilk original test. This test facilitates the use of a small number of sample components, e.g., 3 to 50 elements. These statistics were supported by skewness and kurtosis calculations for each time series of air variables (Table S7). Bivariate correlation analysis was applied to reveal certain elemental relationships in TSP. Enrichment factors (EFs) for each quantified element have been calculated as described by Papp and Kümmel (1992), utilizing $\mathrm{Al}$ or $\mathrm{Si}$ as a reference. No significant difference was observed between the EF values obtained with $\mathrm{Al}$ and Si.

Approximate aerosol mass closure calculations were performed by utilizing the acquired elemental data and the method of chemical boundary conditions (CBC). This method takes into an account a couple of key (acidic-basic) chemical reactions occurring in the troposphere (Anaf et al. 2012, 2013). Briefly, it calculates the air levels of certain aerosol components, such as $\mathrm{NaCl}, \mathrm{NaNO}_{3},\left(\mathrm{NH}_{4}\right)_{2} \mathrm{SO}_{4}, \mathrm{NH}_{4}{ }^{+}$, aged sea salt-bound $\mathrm{NO}_{3}{ }^{-}$, and $\mathrm{SO}_{4}{ }^{2-}$, described in detail by Anaf et al. (2012). The water content of aerosol species was modeled by means of a single-parameter estimation approach, as suggested by Kreidenweis et al. (2008). In part of these calculations, the aerosol density data, reported by Zelenyuk et al. (2005), were utilized too. The literature $\mathrm{PM}_{10}, \mathrm{PM}_{2.5}$, and aerosol sulfate and nitrate values were compared with the current results for TSP after normalization by taking into account certain multiplication factors (Brook et al. 1997; Tsai et al. 2005). The air quality index (AQI) was calculated on the basis of the US EPA (2020) recommendation. Model calculations have been performed with the WHO's $\mathrm{AIRQ}^{+}$(2020) software to predict the long-term negative health effects of air pollution burden on the local population by taking into account the acquired daily atmospheric aerosol concentration.

For ammonium and nitrate aerosols, of which air concentration was inaccessible with the presently applied methodology, approximate values were calculated on the basis of previous observations in the city for coastal and semi-urban sites (Mmari et al. 2013). For this purpose, bivariate correlations between the formerly acquired data on ionic TSP species were evaluated first, and their mass ratios were calculated to find proper diagnostic ratios (Table S8), which could be applied as suitable multiplication factors for estimating ammonium and nitrate air levels at the current study sites. On the basis of strong correlations, ratios of $\mathrm{SO}_{4}{ }^{2-}$ to $\mathrm{NH}_{4}{ }^{+}$and $\mathrm{NO}_{3}{ }^{-}$to $\mathrm{Cl}^{-}$ were found to be appropriate. For instance, the average $( \pm \mathrm{SD})$ $\mathrm{SO}_{4}{ }^{2-}$-to- $\mathrm{NH}_{4}{ }^{+}$ratio for the coastal site was $11.3 \pm 1.5$ (median: 11.1), as well as for the semi-urban site, it reached a close value, i.e., $10.4 \pm 4.1$ (median: 11 ). On the other hand, the average $\mathrm{NO}_{3}{ }^{-}$-to- $\mathrm{Cl}^{-}$ratio was found to be lower, i.e., at a coastal site, it was $2.6 \pm 1.0$ (median: 2.1), and likewise at a semi-urban site, it was $2.5 \pm 1.1$ (median: 2.2 ). Similarly, the average $\mathrm{NO}_{3}{ }^{-}$-to- $\mathrm{NH}_{4}{ }^{+}$ratio at the coastal site was $2.2 \pm 0.9$ (median: 2.3), and at the semi-urban site, it was $2.9 \pm 1.8$ (median: 2.9). Due to their relative close values, these factors were applied to estimate the $\mathrm{NH}_{4}{ }^{+}$and $\mathrm{NO}_{3}{ }^{-}$concentrations with the daily $\mathrm{SO}_{4}{ }^{2-}$ and $\mathrm{Cl}^{-}$values at the present study sites.

The mineral aerosol concentration $\left(c_{\mathrm{ma}}\right)$ has been calculated with the formula $c_{\mathrm{ma}}=2.2 c_{\mathrm{Al}}+2.49 c_{\mathrm{Si}}+1.63 c_{\mathrm{Ca}}+$ $2.42 c_{\mathrm{Fe}}+1.94 c_{\mathrm{Ti}}$ as described elsewhere (IMPROVE 2020). Ti was not included in this calculus, due to its fairly low air level in the city (Mkoma et al. 2009b) and the limitations in detection with the applied methodology. It should be noted that in this study, neither elemental carbon (EC) nor organic matter $(\mathrm{OM}$, calculated from organic carbon (OC) mass as $\mathrm{OM}=1.6 \times \mathrm{OC}$ ) was quantitated in lack of proper instrumentation. These aerosol constituents could be significant contributors to PM mass at the present study sites. For example, Mkoma et al. (2009b) observed as high contribution as 30\% of $\mathrm{EC}+\mathrm{OM}$ to $\mathrm{PM}_{10}$ at urban sites of Dar es Salaam. Thus, these data were taken into account as indicative values in estimating the contribution of EC and OM to current PM data, after certain normalization to daily TSP mass.

\section{Results and discussion}

\section{Air concentrations of elemental and ionic species}

\section{Total elemental concentrations and contributions}

The average elemental concentration was the highest at Ubungo $\left(41 \pm 11 \mu \mathrm{g} / \mathrm{m}^{3}\right)$, the site being located the farthest 
from the sea, with a heavy traffic bus station and a nearby gas power plant, followed by the Jangwani site $\left(34 \pm 8 \mu \mathrm{g} / \mathrm{m}^{3}\right)$ (Table S5). Compared with them, the other study sites, Kariakoo and Chang'ombe, had much lower mean elemental content, i.e., $20 \pm 6 \mu \mathrm{g} / \mathrm{m}^{3}$ and $26 \pm 5 \mu \mathrm{g} / \mathrm{m}^{3}$, respectively. The main aerosol components appeared to be crustal (Al, Ca, Si), sea spray related $(\mathrm{Cl}, \mathrm{Mg}, \mathrm{Na})$, and anthropogenic $(\mathrm{S})$, each usually with a concentration higher than $1 \mu \mathrm{g} / \mathrm{m}^{3}$. On the other hand, most elements of anthropogenic origin had in general much lower air levels. The average concentrations of some anthropogenic/crustal elements ( $\mathrm{Br}, \mathrm{Cd}, \mathrm{Cu}, \mathrm{Fe}, \mathrm{Mn}, \mathrm{Ni})$ hardly changed over the sampling sites, whereas another set of elements, like $\mathrm{As}, \mathrm{Cr}, \mathrm{K}, \mathrm{Pb}, \mathrm{S}, \mathrm{Sb}$, and $\mathrm{Zn}$, showed considerable variations.

The site-specific variation of aerosol components follows a rather general trend, similar to that obtained for the summed (total) elemental concentration as above and for crustal and sea spray related aerosols. Namely, the Ubungo site (bus terminal) showed the highest total average concentrations of anthropogenic elements, such as $\mathrm{As}, \mathrm{Br}, \mathrm{Cd}, \mathrm{Cr}, \mathrm{Cu}, \mathrm{K}, \mathrm{Mn}, \mathrm{Ni}$, $\mathrm{Pb}, \mathrm{Sb}$, and $\mathrm{Zn}\left(9.3 \mu \mathrm{g} / \mathrm{m}^{3}\right)$, followed by lower values over the other three sites, Kariakoo $\left(6.2 \mu \mathrm{g} / \mathrm{m}^{3}\right)$, Jangwani $\left(6.1 \mu \mathrm{g} / \mathrm{m}^{3}\right)$, and Chang'ombe $\left(5.5 \mu \mathrm{g} / \mathrm{m}^{3}\right)$. Coal burning, for instance, in power stations, is a source of $\mathrm{Pb}$ and $\mathrm{Zn}$, but this activity increases the air levels of other toxic metals, such as $\mathrm{Cd}, \mathrm{Cr}$, $\mathrm{Cu}$, and $\mathrm{Ni}$ (Keegan et al. 2006). The brake lining and tire tread wear of motor vehicles has also been reported as a major source of $\mathrm{Cd}, \mathrm{Cu}, \mathrm{Pb}, \mathrm{Sb}$, and $\mathrm{Zn}$ in urban areas (Hjortenkrans et al. 2007). In Tanzania, $\mathrm{Zn}$ is generally referred to as a marker of industrial activity (Mkoma et al. 2009a) and/or motor vehicular traffic (Bennet et al. 2005).

\section{Mineral content}

The mineral mass of TSP for the Kariakoo site was ranging from 7 to $39 \mu \mathrm{g} / \mathrm{m}^{3}$ with an average value of $18 \pm 11 \mu \mathrm{g} / \mathrm{m}^{3}$. A fairly low mineral concentration was observed for the Chang'ombe site, in the range of 18 to $44 \mu \mathrm{g} / \mathrm{m}^{3}$ (mean: 26 $\pm 8 \mu \mathrm{g} / \mathrm{m}^{3}$ ). The other study sites were characterized with much higher mineral aerosol content. For Jangwani, it was in the range of 26 to $64 \mu \mathrm{g} / \mathrm{m}^{3}$ (mean: $40 \pm 13 \mu \mathrm{g} / \mathrm{m}^{3}$ ), while for the Ubungo station, it was lying between 21 and $103 \mu \mathrm{g} /$ $\mathrm{m}^{3}$ (average: $50 \pm 24 \mu \mathrm{g} / \mathrm{m}^{3}$ ). These sites are characterized with continuous and fairly dense traffic of heavy motor vehicles, which contribute considerably to the mineral content of aerosols, mostly by resuspension of road dust.

\section{Total aerosol sulfate}

Sulfate was calculated from the aerosol S content determined by means of WDXRF, assuming that all of the aerosol sulfur is in the form of $\mathrm{SO}_{4}{ }^{2-}$ salts. This approach is a good estimate of sulfate in view of former, comparative EDXRF and ion chromatography studies on Tanzanian aerosols (Mkoma et al. 2009a). At the Kariakoo site, the total sulfate content of aerosols was relatively low, ranging between 1.9 and $2.8 \mu \mathrm{g} / \mathrm{m}^{3}$ (mean: $2.3 \pm 0.3 \mu \mathrm{g} / \mathrm{m}^{3}$ ). This urban site is characterized with less dense traffic than the others, which provides it with lower aerosol sulfate levels, due to lower exposure to diesel emissions. At the other sampling sites, i.e., Jangwani, Chang'ombe, and Ubungo, the aerosol $\mathrm{SO}_{4}{ }^{2-}$ concentration was significantly higher, ranging between $4.6-10.1 \mu \mathrm{g} / \mathrm{m}^{3}$ (average: $7.2 \pm 1.8 \mu \mathrm{g} / \mathrm{m}^{3}$ ), $4.1-8.3 \mu \mathrm{g} / \mathrm{m}^{3}$ (average: $6.0 \pm$ $1.4 \mu \mathrm{g} / \mathrm{m}^{3}$ ), and $4.3-10 \mu \mathrm{g} / \mathrm{m}^{3}$ (average: $7.0 \pm 1.8 \mu \mathrm{g} / \mathrm{m}^{3}$ ), respectively. These data reveal an approximately 1.5 to 2 fold concentration increase compared with those observed in Dar es Salaam in 2005-2007 for daily PM $_{10}$ (TSP equivalent median: $3.1 \pm 1.1 \mu \mathrm{g} / \mathrm{m}^{3}$ ) (Mkoma et al. 2009a) and for daytime TSP (median: $3.9-4.7 \mu \mathrm{g} / \mathrm{m}^{3}$ ) as well (Mmari et al. 2013). The rather modest increase is due to the combined effects of the growth in the vehicle fleet and related traffic density and to strict fuel quality legislations introduced before the study period, e.g., sulfur limit of 500 ppm for diesel fuel used in combustion engines for motor vehicles.

\section{Estimate of ammonium and nitrate aerosol content}

At the commercial site (Kariakoo), the $\mathrm{NH}_{4}{ }^{+}$concentration was low compared with the other sites, ranging between 0.18 and $0.25 \mu \mathrm{g} / \mathrm{m}^{3}$ (average: $0.21 \pm 0.03 \mu \mathrm{g} / \mathrm{m}^{3}$ ). At Jangwani and Ubungo sites, the $\mathrm{NH}_{4}{ }^{+}$concentrations fell into similar ranges, i.e., from $\approx 0.4$ to $0.91 \mu \mathrm{g} / \mathrm{m}^{3}$, with averages of $0.65 \pm 0.17 \mu \mathrm{g} / \mathrm{m}^{3}$ and $0.63 \pm 0.16 \mu \mathrm{g} / \mathrm{m}^{3}$, respectively. Slightly lower aerosol $\mathrm{NH}_{4}{ }^{+}$levels were estimated for the industrial Chang'ombe site, ranging from 0.37 to $0.75 \mu \mathrm{g}$ / $\mathrm{m}^{3}$ (mean: $0.55 \pm 0.13 \mu \mathrm{g} / \mathrm{m}^{3}$ ). In general, the aerosol $\mathrm{NH}_{4}^{+}$ levels were found to be a bit increased as compared with those reported in former studies from the city, e.g., median of $0.094 \mu \mathrm{g} / \mathrm{m}^{3}$ in $\mathrm{PM}_{10}$ for the wet season (Mkoma et al. 2009 b), but commensurable with those observed for daytime TSP $\left(0.24-0.35 \mu \mathrm{g} / \mathrm{m}^{3}\right)$ (Mmari et al. 2013), though the heavy trafficked sites showed twice higher levels.

Similar trends for nitrate aerosols have been observed as found for $\mathrm{NH}_{4}{ }^{+}$. The estimated air level of nitrate at the Kariakoo site was relatively low, ranging from 0.13 to $0.97 \mu \mathrm{g} / \mathrm{m}^{3}$ (average: $0.57 \pm 0.24 \mu \mathrm{g} / \mathrm{m}^{3}$ ). Higher $\mathrm{NO}_{3}{ }^{-}$air concentrations were observed for the Jangwani site, fluctuating between 0.45 and $1.35 \mu \mathrm{g} / \mathrm{m}^{3}$ (average: $0.79 \pm 0.28 \mu \mathrm{g}$ / $\mathrm{m}^{3}$ ). At the heavy trafficked (Ubungo) and industrial (Chang'ombe) sites, similar $\mathrm{NO}_{3}{ }^{-}$air levels were obtained, ranging between 0.5 and $0.9 \mu \mathrm{g} / \mathrm{m}^{3}$ (averages: $0.74 \pm$ $0.15 \mu \mathrm{g} / \mathrm{m}^{3}$ and $0.71 \pm 0.11 \mu \mathrm{g} / \mathrm{m}^{3}$, respectively). The nitrate levels at the four study sites are commensurable with those observed in $\mathrm{PM}_{10}$ of Dar es Salaam, reporting normalized TSP equivalent of $0.29-1.31 \mu \mathrm{g} / \mathrm{m}^{3}$ with a median of $0.93 \mu \mathrm{g} / \mathrm{m}^{3}$ (Mkoma et al. 2009b) and those determined in TSP ranging 
from 0.4 to $1.32 \mu \mathrm{g} / \mathrm{m}^{3}$ with a median value of $0.82 \mu \mathrm{g} / \mathrm{m}^{3}$ (Mmari et al. 2013).

\section{Enrichment factors}

The EF values for the sampling sites are significantly higher than 1000 for $\mathrm{As}, \mathrm{Br}, \mathrm{Cd}$, and $\mathrm{Sb}$, whereas they are generally ranging between 100 and 1000 for $\mathrm{Cr}, \mathrm{Ni}, \mathrm{Pb}$, and $\mathrm{Zn}$ (Fig. 2). Still, the EFs of a few aerosol components, like $\mathrm{Cu}$ and $\mathrm{S}$, are lying in the range, which suggests anthropogenic origin (EFs $\approx 50$ ). Apparently, less accumulation of Mn in TSP was observed (EF: 8-32). The EF values for $\mathrm{Cl}$ are fairly high too (range: 40-100), but this element is well-known to stem mostly from marine aerosol. The EFs for $\mathrm{Na}$ are rather low, usually around 5-8, showing its low, natural accumulation in TSP, originating dominantly from sea spray, formed over open oceanic waters and transported towards the continent. Only the Kariakoo site showed a bit higher EF values for $\mathrm{Na}$ and $\mathrm{Cl}$, which could be due to its closer distance $(\approx 2 \mathrm{~km})$ to the ocean (Fig. 1). The low EFs $(<3)$ for $\mathrm{Al}, \mathrm{Ca}, \mathrm{Fe}$, and Si suggest that their origin is mostly from crustal/upper soil (Fig. 2).

\section{Ratios of various aerosol constituents in Dar es Salaam aerosols}

\section{Elemental/species ratios of sea spray components}

The $\mathrm{Mg}^{2+}$-to- $\mathrm{Na}^{+}$ratios for TSP are similar (Kariakoo and Chang'ombe) or slightly higher (Ubungo and Jangwani) than the corresponding elemental ratio in sea water (Fig. 3). It follows from this finding that a considerable part (64-100\%) of $\mathrm{Mg}^{2+}$ originates from sea spray at the sites closer to the ocean. In contrast, other ionic species stem either from anthropogenic emissions $\left(\mathrm{K}^{+}, \mathrm{Br}^{-}, \mathrm{SO}_{4}{ }^{2-}\right)$ and/or crustal sources $\left(\mathrm{Ca}^{2+}\right)$. At the Chang'ombe (industrial) and Jangwani (mixed urban) sites, only about $20 \%$ of particulate $\mathrm{SO}_{4}{ }^{2-}$ comes from aerosols formed over the open sea, while at the Kariakoo commercial area, higher sea salt $\mathrm{SO}_{4}{ }^{2-}$ contribution $(\approx 30 \%)$ has been observed. On the other hand, the increased $\mathrm{SO}_{4}{ }^{2}$ ${ }^{-} / \mathrm{Na}^{+}$ratios at the Ubungo (heavy trafficked) site indicate the highly increased contribution of terrestrial (mostly anthropogenic) emissions $(\approx 85 \%)$ to sulfate PM. The significantly (9 to 24-fold) higher $\mathrm{Ca}^{2+} / \mathrm{Na}^{+}$ratios in TSP at the sampling sites compared with that in sea water indicate that $\mathrm{Ca}$ is of terrestrial (mostly crustal/upper soil) origin. Similarly, highly increased $\mathrm{Br}^{-} / \mathrm{Na}^{+}$ratios were obtained for the study sites, as compared with the corresponding ratio for sea water, indicating the origin of most $\mathrm{Br}^{-}$from terrestrial (anthropogenic) sources. The fairly low $\mathrm{Cl}^{-} / \mathrm{Na}^{+}$ratios found in TSP $(0.32-$ 0.56 ) can be attributed to the high conversion rate of sea spray aerosol. Conversion of sea spray starts immediately after its formation over the sea, which aging effect is more intense for fine particulate (Kerminen et al. 2001) and at coastal regions with high anthropogenic influence (Horemans et al. 2009). These considerations appear to be valid for the current sampling sites.

\section{Elemental ratios of anthropogenic aerosol components}

The concentration ratios of elements detected in TSP were calculated in order to find apt diagnostic ratios, which could assist in identifying emission sources influencing the air quality at the study sites (Table S6). Formerly, Bennet et al. (2005) used $\mathrm{Br} / \mathrm{Pb}$ statistics as a diagnostic ratio for fresh motor vehicle exhaust aerosol in Dar es Salaam as was found in the antiknock agent utilized in the fuel. In Sweden, before phasing out the $\mathrm{Pb}$-based anti-knocking agents from fuel, $\mathrm{a} \mathrm{Br} / \mathrm{Pb}$ ratio of 0.34 was observed in urban aerosols (Öblad and Selin 1985), whereas for equatorial East African cities of Kinshasa (Congo) and Butare (Rwanda), a daytime ratio of $0.31 \pm 0.09$ and $0.43 \pm 0.03$, respectively, was reported (Maenhaut and Akilimali 1987). In Tanzania, there had been no legislated
Fig. 2 Enrichment factors for various aerosol components at the four sampling stations in Dar es Salaam calculated for $\mathrm{Si}$ as a reference element

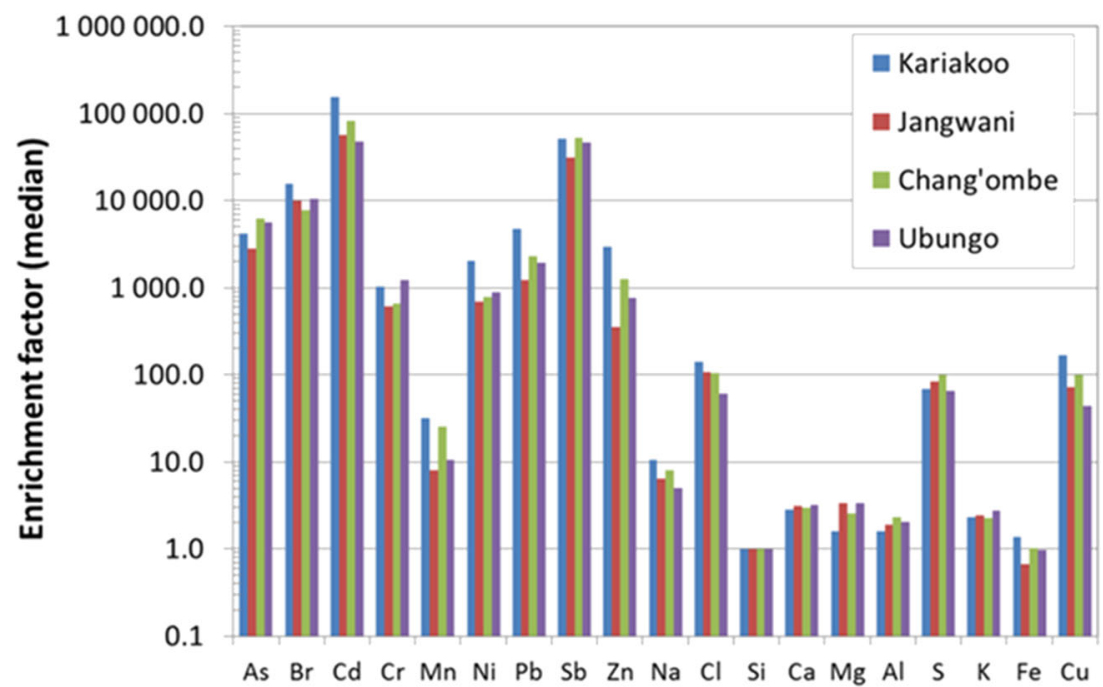


Fig. 3 Average concentration ratios of various sea spray components to sodium in aerosols and their fluctuations (expressed as $\pm \mathrm{SD}$ ), over the four study sites in Dar es Salaam, and the corresponding elemental ratios in sea water used as references

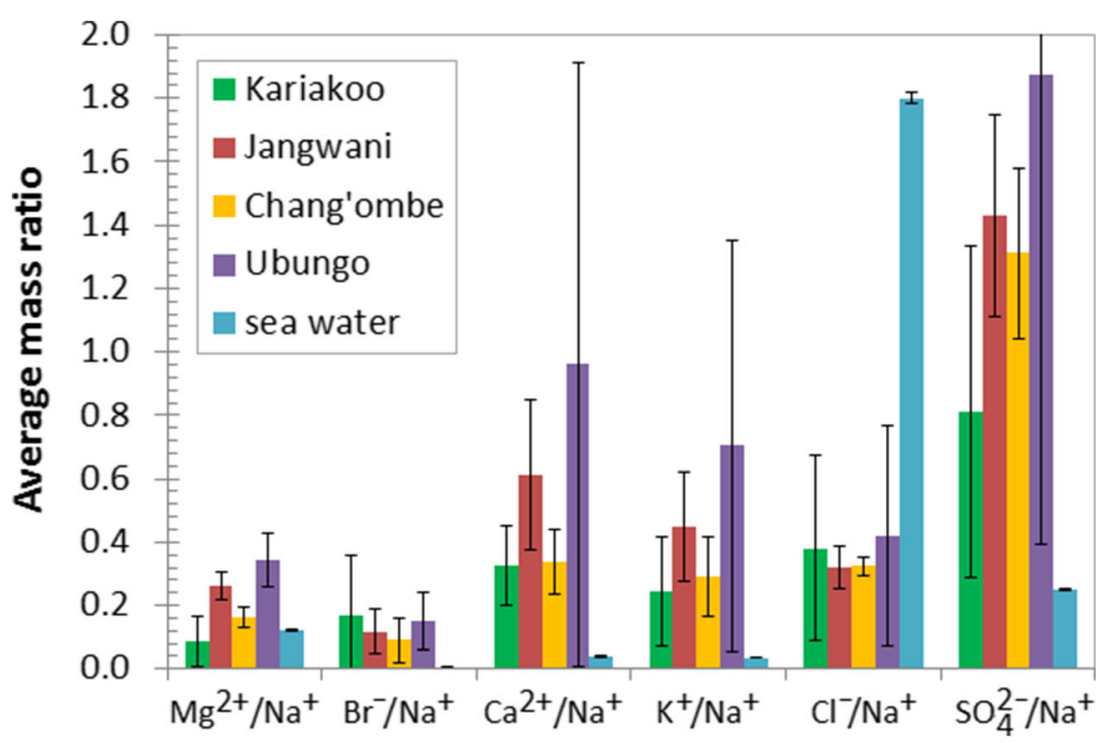

standard until the end of 2005, regarding the $\mathrm{Pb}$ content of commercial fuel. Accordingly, Bennet et al. (2005) reported a $\mathrm{Br} / \mathrm{Pb}$ ratio of $<1.2$ for urban sites of Dar es Salaam for October and May (wet season) with averages of 0.3 and 0.5 , respectively. In contrast, higher values $(>1.5)$ were observed for rural sites, ranging up to 11 , which implied another source of $\mathrm{Br}$, e.g., biomass burning. In the current study, the $\mathrm{Pb} / \mathrm{Br}$ ratio encountered a wide fluctuation from site to site (Table S6), i.e., between 1.3 and 5.4 with an average of 2.8 \pm 1.8 . This fluctuation is likely due to multiple sources of $\mathrm{Pb}$, e.g., reduced emissions from traffic and more prevalence of industrial sources, like battery (Mkoma et al. 2009b) and paint production/use, as well as resuspension of soil/road dust with fairly high, accumulated $\mathrm{Pb}$ content. These conditions make the utilization of the $\mathrm{Pb} / \mathrm{Br}$ ratio for source diagnostic purposes rather difficult. Consequently, other elemental ratios with relatively low fluctuations have been evaluated (Table S6). For instance, the $\mathrm{Br} / \mathrm{Ni}$ ratio ranged between 1.0 and 1.7 with a mean of $1.3 \pm 0.3$, while the $\mathrm{Br} / \mathrm{Sb}$ ratio ranged between 1.4 and 2.3 (average: $1.8 \pm 0.5$ ). Bromine nowadays is mostly utilized as a flame retardant, e.g., additive in the plastic and electronic industry, but it also comes from combustion of heavy diesel oil (Bencs et al. 2010). As known, Ni in aerosols mainly originates from residual oil burning, e.g., diesel (Maenhaut et al. 1996), but partly from brake lining wear too (Hjortenkrans et al. 2007). Interestingly, for the current study sites, the $\mathrm{Ni} / \mathrm{Sb}$ ratio ranged between 1.3 and 2.0 (mean: $1.6 \pm 0.3)$, which is lower than that reported for urban sites (2.6) (Hjortenkrans et al. 2007).

Wang et al. (2003) reported data on emissions of trace elements from a diesel-fuelled engine, from which one can calculate certain elemental ratios, applicable to this study, such as $\mathrm{Pb} / \mathrm{Ni}$ (0.8), Ni/Sb (2.7), Ni/Cd (4.5), $\mathrm{Sb} / \mathrm{Cd}$ (1.8), $\mathrm{Zn} / \mathrm{Cd}$ (10.4), $\mathrm{Zn} / \mathrm{Sb}$ (5.9), and $\mathrm{Zn} / \mathrm{Pb}$ (2.7). On the basis of these data, a few of the currently evaluated average elemental ratios (e.g., Ni/Cd: $3.0 \pm 1.3 ; \mathrm{Sb} / \mathrm{Cd}: 2.2 \pm 1.1 ; \mathrm{Zn} / \mathrm{Cd}: 9.1 \pm 4.4 ; \mathrm{Zn} /$ Sb: $5.1 \pm 3.3$ ) demonstrate the impact of vehicular traffic (e.g., exhaust of diesel combustion) over the study sites, while further elemental ratios reveal the contribution of other or more than one source to the elemental content of TSP, such as $\mathrm{Pb} / \mathrm{Ni}$ $(2.5 \pm 0.2), \mathrm{Cd} / \mathrm{Cu}(7.6 \pm 1.8), \mathrm{Zn} / \mathrm{Pb}(7.0 \pm 5.5)$, and $\mathrm{Ni} / \mathrm{Sb}$ as noted above.

\section{Correlations of elements in aerosols}

At the present study sites, $\mathrm{Al}, \mathrm{Ca}$, and $\mathrm{Si}$ showed strong correlation with each other and generally with $\mathrm{Fe}$ too, elements which are mostly of crustal/upper soil origin (Tables S9-S12). The major sea salt aerosol components $(\mathrm{Na}, \mathrm{Cl}, \mathrm{Mg}$, and $\mathrm{S}$ ) usually correlated strongly with each other too.

At the heavily trafficked Ubungo site, As fairly strongly correlated with $\mathrm{Cu}$ and $\mathrm{Cl}$, but showed lower correlation with $\mathrm{S}$, pointing to the usage of As in corrosion-resistant $\mathrm{Cu}$ alloys. Br strongly correlated with $\mathrm{Si}$ but weakly correlated with $\mathrm{Cr}$, $\mathrm{Ni}$, and $\mathrm{Sb}$. This finding shows that the main source of $\mathrm{Br}$ is likely the resuspended road dust, to which it comes primarily from combustion of diesel oil used in local transport vehicles. Mn correlated strongly with $\mathrm{Al}$ and $\mathrm{Mg}$, somewhat weakly with Fe, but anti-correlated with anthropogenic elements, such as $\mathrm{Sb}$ and $\mathrm{Zn}$, pointing towards the origin of $\mathrm{Mn}$ from crustal sources. Lead was in general weakly anti-correlated with crustal and sea spray components, which shows evidently that $\mathrm{Pb}$ comes from anthropogenic emissions, most possibly multiple sources as noted in the previous section. Zinc developed some correlation with $\mathrm{Sb}$ but anti-correlation with $\mathrm{Al}, \mathrm{Fe}, \mathrm{Mg}$, $\mathrm{Mn}, \mathrm{Na}$, and $\mathrm{S}$, which indicates that $\mathrm{Zn}$ originates partly from non-exhaust emissions of the local traffic, besides other anthropogenic (industrial) sources. In addition to $\mathrm{Zn}$, Sb weakly correlated with $\mathrm{Cu}$ and $\mathrm{Br}$, pointing to non-exhaust emissions of the local traffic. Moreover, industrial emission, e.g., waste 
fly ash, is another likely source of Sb (Iijuma et al. 2009). Calcium correlated weakly with $S$ and $K$, revealing that a part of Ca may originate from biomass burning, besides the crustal origin.

At the Jangwani site, being characterized with stop-and-go traffic and road reconstruction works, interestingly, S showed strong correlation with $\mathrm{K}$ and crustal components, which point towards sources of resuspended soil/road dust. Arsenic weakly correlated with $\mathrm{Cd}$ and $\mathrm{Si}$, but anti-correlated with $\mathrm{Br}, \mathrm{Cr}$, and $\mathrm{Ni}$ (traffic/diesel emission related elements). Br showed anti-correlation with crustal elements, $\mathrm{Mg}$ and $\mathrm{K}$, while $\mathrm{Cd}$ well correlated with $\mathrm{Cu}$ but anti-correlated with $\mathrm{Na}, \mathrm{Mg}, \mathrm{S}$, and $\mathrm{Cr}$. These results suggest the presence of diesel emissions from traffic and/or from nearby power generators. $\mathrm{Cr}$ correlated weakly with $\mathrm{Na}, \mathrm{Ni}$, and $\mathrm{Sb}$, indicating the nearby presence of garages and the related non-exhaust emissions (brake lining and tire wear), while $\mathrm{Pb}$ showed weak anti-correlation with $\mathrm{Na}, \mathrm{Cl}$, and $\mathrm{Zn}$. Zinc correlated quite strongly with $\mathrm{Cl}$, while its weaker correlation was observed with $\mathrm{Na}, \mathrm{Mg}$, and $\mathrm{K}$, pointing to emissions from cook stoves.

At the industrial Chang'ombe site, As correlated fairly well with $\mathrm{Mn}$, but less strongly with $\mathrm{S}$, and anti-correlated with $\mathrm{Pb}$. Br correlated quite well with $\mathrm{Cu}$ but showed somewhat lower correlation with $\mathrm{Pb}$, while $\mathrm{Cu}$ correlated weakly with $\mathrm{Ni}, \mathrm{Pb}$, and $\mathrm{Sb}$ too. $\mathrm{Ni}$ also correlated weakly with $\mathrm{Cd}, \mathrm{Sb}$, and $\mathrm{Zn}$. As known, $\mathrm{Br}, \mathrm{Cu}$, and $\mathrm{Ni}$ are common markers of oil combustion in tropospheric aerosols (Pio et al. 1989). Accordingly, these correlations point towards diesel/residual oil burning sources for the concerned elements. $\mathrm{Cr}$ showed anti-correlation with $\mathrm{K}, \mathrm{Ni}$, and $\mathrm{Zn}$, whereas it correlated with $\mathrm{Fe}$, pointing towards the emissions from mechanical workshops. Mn was found to correlate loosely with crustal components and also with $\mathrm{S}$ and $\mathrm{K}$, showing its origin partly from resuspended soil and partly biomass burning. The observed moderate EF value for Mn supports this assumption (cf. Fig. 2).

The Kariakoo sampling site showed correlations of As with $\mathrm{Cu}, \mathrm{Ca}$, and $\mathrm{Si}$, but its anti-correlation with vehicular emission released elements (e.g., $\mathrm{Br}, \mathrm{Cd}, \mathrm{Cr}, \mathrm{Zn}$ ). This finding points towards the origin of $\mathrm{As}$ and $\mathrm{Cu}$ from welding, applied in renovation of buildings and/or a nearby industrial $\mathrm{Cu}$ smelter. $\mathrm{Br}$ moderately correlated with $\mathrm{Cd}$, $\mathrm{Mn}, \mathrm{Ni}$, and $\mathrm{Zn}$ but anti-correlated with $\mathrm{Cu}$, whereas $\mathrm{Mn}$ strongly correlated with $\mathrm{Ni}$ and fairly well with $\mathrm{Zn}$, while $\mathrm{Ni}$ correlated rather well with $\mathrm{Zn}$ but, interestingly, anticorrelated with $\mathrm{Cu}, \mathrm{Fe}$, and $\mathrm{S}$. These observations point towards the source of $\mathrm{Br}, \mathrm{Mn}, \mathrm{Ni}$, and partly, $\mathrm{Cd}$ and $\mathrm{Zn}$ in local, diesel motor vehicular emissions. $\mathrm{Cr}$ correlated quite well with $\mathrm{Pb}$ and less strongly with $\mathrm{Mg}$, which likely shows the emissions of coke ovens (Wang et al. 2003). Sb correlated with $\mathrm{Cl}$ and $\mathrm{Mg}$, which is likely due to waste burning/incineration activities at local markets.

\section{Species concentrations and contributions to aerosol mass}

At the Kariakoo sampling site, the summed concentrations of the aerosol constituents to TSP ranged from 18 to $59 \mu \mathrm{g} / \mathrm{m}^{3}$ with an average of $35 \mu \mathrm{g} / \mathrm{m}^{3}$ (Fig. 4). Mineral components contributed significantly to PM mass, ranging from 6.5 to $39 \mu \mathrm{g} / \mathrm{m}^{3}$ (average: $18.5 \mu \mathrm{g} / \mathrm{m}^{3}$ ), whereas genuine sea salt to a lower extent, fluctuating from 2.2 to $10.8 \mu \mathrm{g} / \mathrm{m}^{3}$ (average: $6.2 \mu \mathrm{g} / \mathrm{m}^{3}$ ). The contribution from anthropogenic elements (As, $\mathrm{Br}, \mathrm{Cd}, \mathrm{Cr}, \mathrm{Cu}, \mathrm{K}, \mathrm{Mn}, \mathrm{Ni}, \mathrm{Pb}, \mathrm{Sb}, \mathrm{Zn}$ ) ranged from 4.5 to $8.9 \mu \mathrm{g} / \mathrm{m}^{3}$ (average: $6.2 \mu \mathrm{g} / \mathrm{m}^{3}$ ). Aged sea salt bound sulfate contributed to TSP to a relatively low extent, i.e., from non-detectable up to $2.1 \mu \mathrm{g} / \mathrm{m}^{3}$ (average: $1.2 \mu \mathrm{g} /$ $\mathrm{m}^{3}$ ), while aged sea salt bound nitrate contributed similarly, e.g., from 0.13 to $1.0 \mu \mathrm{g} / \mathrm{m}^{3}$ (average: $0.57 \mu \mathrm{g} / \mathrm{m}^{3}$ ). The contribution from ammonium salts of nitrate and sulfate was negligibly low. The water content of ionic aerosol was fluctuating between 1.4 and $3.8 \mu \mathrm{g} / \mathrm{m}^{3}$ (average: $2.6 \mu \mathrm{g} / \mathrm{m}^{3}$ ).

At the Jangwani site, the summed concentration of various TSP species was ranging between 49 and $98 \mu \mathrm{g} / \mathrm{m}^{3}$ with an average of $68 \mu \mathrm{g} / \mathrm{m}^{3}$, which is much higher contribution than that observed for the Kariakoo site. The main contribution came from mineral elements, ranging from 26 to $64 \mu \mathrm{g} / \mathrm{m}^{3}$ with an average of $40 \mu \mathrm{g} / \mathrm{m}^{3}$, which is possibly due to the resuspended road dust. The contribution of genuine sea salt was considerable as well, ranging from 6.6 to $13.4 \mu \mathrm{g} / \mathrm{m}^{3}$ (average: $9.6 \mu \mathrm{g} / \mathrm{m}^{3}$ ). Aged sea salt bound sulfate showed much enhanced contribution at this site, fluctuating from 3.5 to $8.2 \mu \mathrm{g} / \mathrm{m}^{3}$ (average: $5.6 \mu \mathrm{g} / \mathrm{m}^{3}$ ), while aged sea salt bound nitrate contributed about 7 times lower on average. Anthropogenic elements contributed from 4.5 to $8.0 \mu \mathrm{g} / \mathrm{m}^{3}$ with an average of $6.2 \mu \mathrm{g} / \mathrm{m}^{3}$, while the water content of aerosol was fluctuating between 3.6 and $7.8 \mu \mathrm{g} /$ $\mathrm{m}^{3}$ (average: $5.5 \mu \mathrm{g} / \mathrm{m}^{3}$ ).

At the Chang'ombe site, the summed contribution of various species to TSP was fluctuating between 40 and $74 \mu \mathrm{g} / \mathrm{m}^{3}$ (average: $50 \mu \mathrm{g} / \mathrm{m}^{3}$ ). Mineral elements contributed to TSP to a fairly high extent, i.e., fluctuating from 18 to $44 \mu \mathrm{g} / \mathrm{m}^{3}$ (mean: $26 \mu \mathrm{g} / \mathrm{m}^{3}$ ). Genuine sea salt showed similar air levels (range: $6.0-10.6 \mu \mathrm{g} / \mathrm{m}^{3}$; average: $8.4 \mu \mathrm{g} / \mathrm{m}^{3}$ ) to those of the former sites, each located relatively close to the ocean. Aged sea salt bound sulfate fluctuated between 2.4 and $6.6 \mu \mathrm{g} / \mathrm{m}^{3}$ (average: $4.6 \mu \mathrm{g} / \mathrm{m}^{3}$ ), while aged sea salt bound nitrate showed around 5 -fold lower levels. Compared with the Jangwani site, anthropogenic elements similar highly contributed, ranging from 3.2 to $7.5 \mu \mathrm{g} / \mathrm{m}^{3}$ with an average of $5.5 \mu \mathrm{g} / \mathrm{m}^{3}$, while the water content of aerosol was fluctuating between 3.0 and $5.9 \mu \mathrm{g} / \mathrm{m}^{3}$ (average: $4.3 \mu \mathrm{g} / \mathrm{m}^{3}$ ). On the other hand, ammonium salts of nitrate and sulfate negligibly contributed to TSP mass.

At the Ubungo station, the contribution of aerosol species to TSP was significantly higher than at the other studied sites, i.e., fluctuating between 52 and $136 \mu \mathrm{g} / \mathrm{m}^{3}$ (average: $80 \mu \mathrm{g} /$ $\mathrm{m}^{3}$ ). Mineral elements contributed significantly to $\mathrm{PM}$ at this 
site too, of which value was ranging from 21 to $103 \mu \mathrm{g} / \mathrm{m}^{3}$ with an average of $50 \mu \mathrm{g} / \mathrm{m}^{3}$. The concentration of anthropogenic elements was fairly high at this site, ranging from 6.5 to $12.7 \mu \mathrm{g} / \mathrm{m}^{3}$ (average: $9.3 \mu \mathrm{g} / \mathrm{m}^{3}$ ). Similar concentrations of genuine sea salt (range: $4.3-11.9 \mu \mathrm{g} / \mathrm{m}^{3}$; average: $9.0 \mu \mathrm{g} / \mathrm{m}^{3}$ ) and somewhat lower air levels of aged sea salt bound sulfate (range: $2.4-8.2 \mu \mathrm{g} / \mathrm{m}^{3}$; average: $5.6 \mu \mathrm{g} / \mathrm{m}^{3}$ ) were observed as compared with the other study sites. The contribution of aged sea salt bound $\mathrm{NO}_{3}{ }^{-}$and $\mathrm{NH}_{4}{ }^{+}$was found to be very low. The relative contributions of various aerosol species with the EC and OM estimates at the four study sites are depicted on Fig. 1.

\section{Air quality index and estimate of long-term health effects}

As a first step, calculations were performed to estimate the daily $\mathrm{PM}_{2.5}$ concentrations on the basis of the observed TSP levels. In these evaluations, EC and OC estimates were included into TSP data, as noticed above. According to these calculations, the Kariakoo, Jangwani, Chang'ombe, and Ubungo sites exhibited $\mathrm{PM}_{2.5}$ concentration ranges of 10-27, 23-43, $19-34$, and $24-60 \mu \mathrm{g} / \mathrm{m}^{3}$ with averages of $18 \pm 6,31 \pm 7,24 \pm$ 5 , and $36 \pm 11 \mu \mathrm{g} / \mathrm{m}^{3}$, respectively. It appears that the average values for Jangwani and Ubungo are outstandingly high, whereas for Kariakoo, it is acceptable, but then again for the industrial Chang'ombe, it is very close to the daily average limit $\left(25 \mu \mathrm{g} / \mathrm{m}^{3}\right)$ recommended by the WHO. Nevertheless, each of them is well above the aimed and recommended yearly average value $\left(10 \mu \mathrm{g} / \mathrm{m}^{3}\right)$, which is the desirable threshold in view of minimizing the negative effects of tropospheric aerosols on human health. The AQI values, calculated for the Kariakoo, Jangwani, Chang'ombe, and Ubungo areas ranged between 47-83, 74-121, 61-96, and 77-153, respectively, with the averages of $62 \pm 12,92 \pm 17,72 \pm 10$, and 103 \pm 24 , respectively. These data correspond to AQI classes of moderate (Kariakoo), moderate/unhealthy for sensitive groups (Jangwani and Chang'ombe), and unhealthy for sensitive groups (Ubungo) categories.

Applying the present PM values and hospitalization data (Mboera et al. 2018), burden of disease calculations for longterm effects of aerosols with the assistance of the WHO's AirQ $^{+}$software predicted increased health risks of the local population at each study area in terms of mortality due to COPD, stroke events, and cardiovascular diseases. For instance, for Kariakoo and Chang'ombe, the number of mortality cases among patient with these diseases showed an increase of $21-32 \%$, whereas for Jangwani and Ubungo, a higher increase of $24-36 \%$ was foreseen.

\section{Conclusions}

The daytime air concentrations of various TSP components were evaluated at four urban sites of Dar es Salaam in June-August, 2014. The results clearly demonstrated considerably increased air pollution, as compared with those data acquired in 2005-2007 (Mmari et al. 2013). The aerosol mineral content was by far found to be the highest
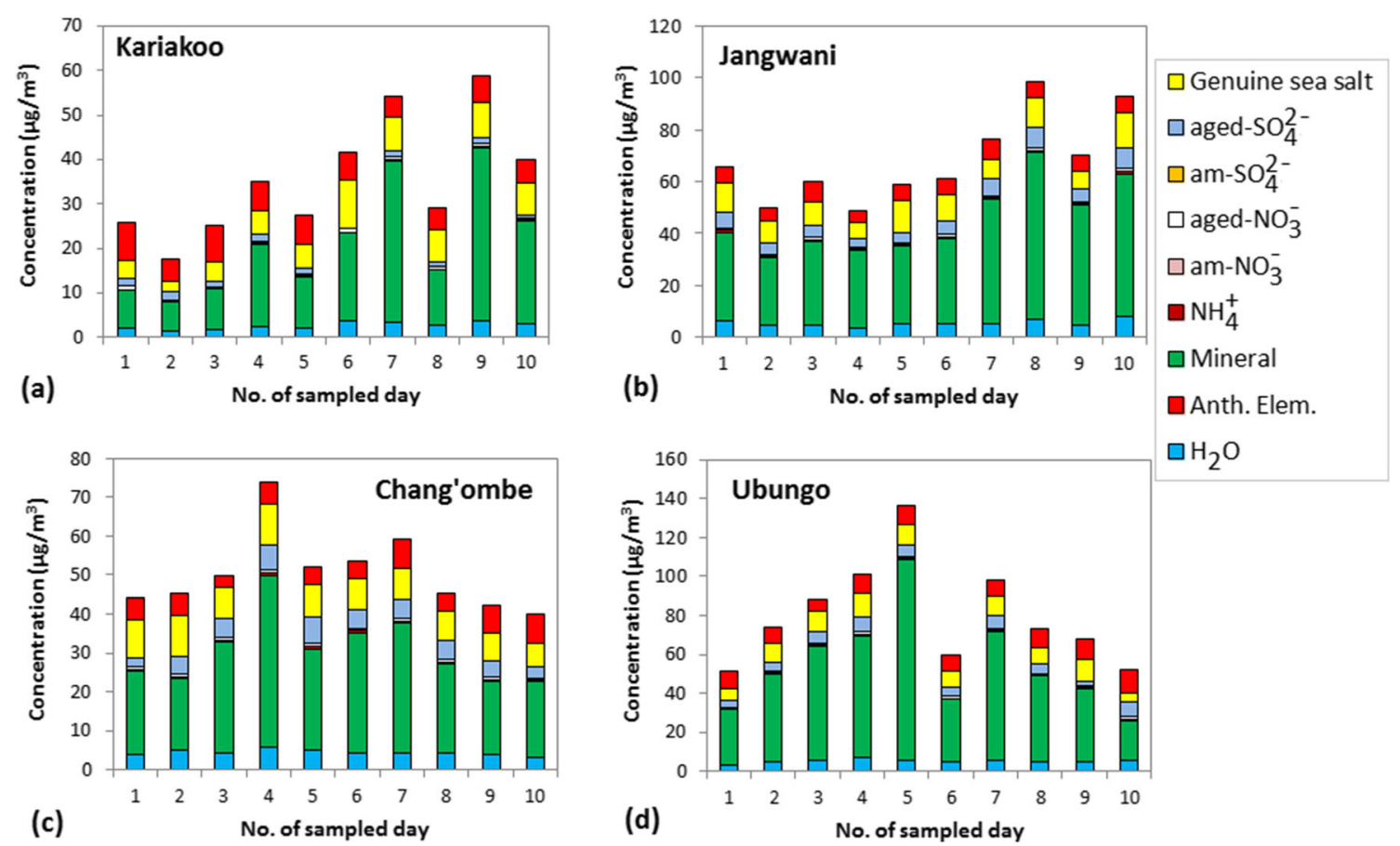

(b)

(d)

Fig. 4 Concentration trends of various species in Dar es Salaam aerosols, sampled over the four sampling sites in June-August, 2014: a Kariakoo, b Jangwani, c Chang'ombe, and d Ubungo 
contributor (averages: $30-40 \%$ ) at the study sites, showing the dominance of resuspended soil/road dust in TSP, though it should be noted that EC+OM could be equally important contributor. Genuine sea salt and aged, sulfatebound sea salt along with their adsorbed water content contributed fairly well to the local aerosol composition, while aged sea salt bound nitrate and ammonium salts appeared to contribute to a much lower degree. Significant increases in concentrations of anthropogenic elements, such as $\mathrm{As}, \mathrm{Br}, \mathrm{Cr}, \mathrm{Cu}, \mathrm{Mn}, \mathrm{Ni}, \mathrm{Pb}$, and $\mathrm{Zn}$, could also be observed. This is a concern and challenge in the fast advancement and modernization of the city, as well as a warning sign towards likely health effects of toxic components on the local population, exposed to a fairly fast raising air pollution burden. Air quality indices and preliminary calculations with the $\mathrm{AirQ}^{+}$model indicate raising health risks and mortality of the sensitive groups of the local population at each study area.

A couple of elemental diagnostic ratios have been proven to be useful for source identification, e.g., for diesel motor vehicle and non-exhaust vehicular emissions, along with utilization of elemental enrichment factors and bivariate correlation analysis. An estimation-based approach was proposed to the nitrate and the ammonium content of the aerosols, which inferred the usability of formerly acquired ratios of these components in tropospheric aerosols for urban sites of Dar es Salaam. The sharper determination of the composition of atmospheric PM could facilitate more accurate source identification and evaluation of the health effects of the local population. The acquired data can help the authorities in establishing proper legislations on the air quality of urban areas under heavy as well as gradually growing anthropogenic impact.

Acknowledgments One of the co-authors (H.A.H.) gratefully thanks the guide provided by Dr. Najat Kassim Mohammed (University of Dar es Salaam, Department of Physics) during his MSc studies.

Funding information Open access funding provided by Wigner Research Centre for Physics.

Open Access This article is licensed under a Creative Commons Attribution 4.0 International License, which permits use, sharing, adaptation, distribution and reproduction in any medium or format, as long as you give appropriate credit to the original author(s) and the source, provide a link to the Creative Commons licence, and indicate if changes were made. The images or other third party material in this article are included in the article's Creative Commons licence, unless indicated otherwise in a credit line to the material. If material is not included in the article's Creative Commons licence and your intended use is not permitted by statutory regulation or exceeds the permitted use, you will need to obtain permission directly from the copyright holder. To view a copy of this licence, visit http://creativecommons.org/licenses/by/4.0/.

\section{References}

Adiang CM, Monkam D, Lenouo A, Njeugna E, Gokhale S (2017) Evaluating impacts of two-wheeler emissions on roadside air quality in the vicinity of a busy traffic intersection in Douala, Cameroon. Air Qual Atmos Health 10:521-532. https://doi.org/10.1007/s11869016-0445-9

Alani RA, Ayejuyo OO, Akinrinade OE, Badmus GO, Festus CJ, Ogunnaike BA, Alo BI (2019) The level $\mathrm{PM}_{2.5}$ and the elemental compositions of some potential receptor locations in Lagos, Nigeria. Air Qual Atmos Health 12:1251-1258. https://doi.org/10.1007/ s11869-019-00743-3

Anaf W, Horemans B, Van Grieken R, De Wael K (2012) Chemical boundary conditions for classification of aerosol particles using computer controlled electron probe microanalysis. Talanta 101: 420-427. https://doi.org/10.1016/j.talanta.2012.09.051

Anaf W, Horemans B, Madeira TI, Carvalho ML, De Wael K, Van Grieken R (2013) Effects of a constructional intervention on airborne and deposited particulate matter in the Portuguese National Tile Museum, Lisbon. Environ Sci Pollut Res 20:1849-1857. https://doi.org/10.1007/s11356-012-1086-7

Baumbach G, Vogt U, Hein KRG, Oluwole AF, Ogunsola OJ, Olaniyi HB, Akeredolu FA (1995) Air pollution in large tropical city with high traffic density - results of measurements in Lagos, Nigeria. Sci Total Environ 169:25-31. https://doi.org/10.1016/0048-9697(95) 04629-F

Bencharif-Madani F, Ali-Khodja H, Kemmouche A, Terrouche A, Lokorai K, Naidja L, Bouziane M (2019) Mass concentrations, seasonal variations, chemical compositions and element sources of $\mathrm{PM}_{10}$ at an urban site in Constantine, northeast Algeria. $\mathrm{J}$ Geochem Explor 206:UNSP 106356. https://doi.org/10.1016/j. gexplo.2019.106356

Bencs L, Ravindra K, de Hoog J, Spolnik Z, Bleux N, Berghmans P, Deutsch F, Roekens E, Van Grieken R (2010) Appraisal of measurement methods, chemical composition and sources of fine atmospheric particles over six different areas of Northern Belgium. Environ Pollut 158:3421-3430. https://doi.org/10.1016/j.envpol.2010.07. 012

Bennet C, Jonsson P, Lindgren ES (2005) Concentrations and sources of trace elements in particulate air pollution, Dar es Salaam, Tanzania, studied by EDXRF. X-Ray Spectrom 34:1-6. https://doi.org/10. 1002/xrs.774

Brook JR, Dann TF, Burnett RT (1997) The relationship among TSP, $\mathrm{PM}_{10}, \mathrm{PM}_{2.5}$ and inorganic constituents of atmospheric particulate matter at multiple Canadian locations. J Air Waste Manage Assoc 47:2-19. https://doi.org/10.1080/10473289.1997.10464407

Fayiga AO, Ipinmoroti MO, Chirenje T (2018) Environmental pollution in Africa. Environ Dev Sustain 20:41-73. https://doi.org/10.1007/ s10668-016-9894-4

Favez O, Cachier H, Sciare J, Alfaro SC, El-Araby TM, Harhash MA, Abdelwahab MM (2008) Seasonality of major aerosol species and their transformation in Cairo megacity. Atmos Environ 42:15031506. https://doi.org/10.1016/j.atmosenv.2007.10.081

Gatebe CK, Tyson PD, Annegarn HJ, Helas G, Kinyua AM, Piketh SJ (2001) Characterization and transport of aerosols over equatorial eastern Africa. Glob Biogeochem Cycles 15:663-672. https://doi. org/10.1029/2000GB001340

Hjortenkrans DST, Bergbäck BG, Häggerud AV (2007) Metal emissions from brake linings and tires: case studies of Stockholm, Sweden 1995/1998 and 2005. Environ Sci Technol 41:5224-5230. https:// doi.org/10.1021/es070198o

Horemans B, Krata A, Buczynska AJ, Dirtu AC, Van Meel K, Van Grieken R, Bencs L (2009) Major ionic species in size-segregated aerosols and associated gaseous pollutants at a coastal site on the 
Belgian North Sea. J Environ Monit 11:670-677. https://doi.org/10. 1039/B815059A

Iijuma A, Sato K, Fujitani Y, Fujimori E, Saito Y, Tanabe K, Ohara T, Kozawa K, Furuta N (2009) Clarification of the predominant emission sources of antimony in airborne particulate matter and estimation of their effects on the atmosphere in Japan. Environ Chem 6: 122-132. https://doi.org/10.1071/EN08107

IMPROVE (Interagency Monitoring of Protected Visual Environments) (2020) http://vista.cira.colostate.edu/improve/tools/aertypeeqs.htm. Accessed 15 April 2020

IPCC (Intergovernmental Panel on Climate Change) (2007) Climate change 2007: the physical science basis. Contribution of Working Group I to the Fourth Assessment Report of the Intergovernmental Panel on Climate Change. Cambridge University Press, New York

Jonsson P, Bennet C, Eliasson I, Lindgren ES (2004) Suspended particulate matter and its relations to the urban climate in Dar es Salaam, Tanzania. Atmos Environ 38:4175-4181. https://doi.org/10.1016/j. atmosenv.2004.04.021

Keegan TJ, Faragó ME, Thornton I, Hong B, Colvile RN, Pesch B, Jakubis P, Nieuwenhuijsen MJ (2006) Dispersion of As and selected heavy metals around a coal-burning power station in Central Slovakia. Sci Total Environ 358:61-71. https://doi.org/10.1016/j. scitotenv.2005.03.020

Kerminen VM, Hillamo R, Teinila K, Pakkanen T, Allegrini I, Sparapani $\mathrm{R}$ (2001) Ion balances of size-resolved tropospheric aerosol samples: implications for the acidity and atmospheric processing of aerosols. Atmos Environ 35:5255-5265. https://doi.org/10.1016/ S1352-2310(01)00345-4

Kinney PL, Gichuru MG, Volavka-Close N, Ngo N, Ndiba PK, Law A, Gachanja A, Gaita SM, Chillrud SN, Sclar E (2011) Traffic impacts on $\mathrm{PM}_{2.5}$ air quality in Nairobi, Kenya. Environ Sci Pol 14:369-378. https://doi.org/10.1016/j.envsci.2011.02.005

Koleleni Y (1998) Air pollution studies of the highest point of the Dar es Salaam City by X-ray fluorescence analysis. Discov Innov 10:170-177. https://doi.org/10.4314/dai.v10i3.15512

Koleleni YIA (2003) Levels of aerosols in Dar es Salaam, Tanzania, compared to some cities. Discov Innov 15:203-212. https://doi. org/10.4314/dai.v15i3.15644

Kreidenweis SM, Petters MD, DeMott PJ (2008) Single-particle estimate of aerosol water content. Environ Res Lett 3(035002):7. https://doi. org/10.1088/1748-9326/3/3/035002

Li J, Pósfai M, Hobbs PV, Buseck PR (2003) Individual aerosol particles from biomass burning in southern Africa: 2. Compositions and aging of inorganic particles. J Geophys Res: Atmos 108, No D13, 8484, pp. 1-12. https://doi.org/10.1029/2002JD002310

Maenhaut W (2008) New directions: future needs for global monitoring and research of aerosol composition. Atmos Environ 42:1070-1072. https://doi.org/10.1016/j.atmosenv.2007.11.038

Maenhaut W, Akilimali K (1987) Study of the atmospheric aerosol composition in equatorial Africa using PIXE as analytical technique. Nucl Instrum Methods Phys Res, Sect B 22:254-258. https://doi. org/10.1016/0168-583X(87)90338-7

Maenhaut W, Salma I, Cafmeyer J, Annegarn HJ, Andreae MO (1996) Regional atmospheric aerosol composition and sources in the eastern Transvaal, South Africa, and impact of biomass burning. J Geophys Res Atmos 101:23631-23650. https://doi.org/10.1029/ 95JD02930

Mboera LEG, Rumisha SF, Lyimo EP, Chiduo MG, Mangu CD, Mremi IR, Kumalija CJ, Joachim C, Kishamawe C, Massawe IS, Matemba LE, Kimario E, Bwana VM, Mkwashapi DM (2018) Cause-specific mortality patterns among hospital deaths in Tanzania, 2006-2015. PLoS One 13:e0205833. https://doi.org/10.1371/journal.pone. 0205833

Mbuligwe SE, Kassenga GR (1997) Automobile air pollution in Dar es Salaam city, Tanzania. Sci Total Environ 199:227-235. https://doi.org/10.1016/S0048-9697(97)05461-2
Mkoma SL (2008) Physico-chemical characterisation of atmospheric aerosols in Tanzania, with emphasis on the carbonaceous aerosol components and on chemical mass closure. PhD thesis, Ghent University, Belgium

Mkoma SL, Wang W, Maenhaut W (2009a) Seasonal variation of watersoluble inorganic species in the coarse and fine atmospheric aerosols at Dar es Salaam, Tanzania. Nucl Instrum Methods Phys Res, Sect B 267:2897-2902. https://doi.org/10.1016/j.nimb.2009.06.099

Mkoma SL, Maenhaut W, Chi X, Raes N (2009b) Characterisation of $\mathrm{PM}_{10}$ atmospheric aerosols for the wet season 2005 at two sites in East Africa. Atmos Environ 43:631-639. https://doi.org/10.1016/j. atmosenv.2008.10.008

Mmari AG, Potgieter-Vermaak SS, Bencs L, McCrindle RI, Van Grieken R (2013) Elemental and ionic components of atmospheric aerosols and associated gaseous pollutants in and near Dar es Salaam, Tanzania. Atmos Environ 77:51-61. https://doi.org/10.1016/j. atmosenv.2013.04.061

Ndetto EL, Matzarakis A (2015) Urban atmospheric environment and human biometeorological studies in Dar es Salaam, Tanzania. Air Qual Atmos Health 8:175-191. https://doi.org/10.1007/s11869014-0261-z

Niyobuhungiro RV, von Blottnitz H (2013) Investigation of arsenic airborne in particulate matter around caterers' wood fires in the Cape Town region. Aerosol Air Qual Res 13:219-224. https://doi. org/10.4209/aaqr.2012.06.0148

Nyanganyura D, Maenhaut W, Mathuthu M, Makarau A, Meixner FX (2007) The chemical composition of tropospheric aerosols and their contributing sources to a continental background site in northern Zimbabwe from 1994 to 2000. Atmos Environ 41:2644-2659. https://doi.org/10.1016/j.atmosenv.2006.11.015

Owoade KO, Hopke PK, Olise FS, Ogundele LT, Fawole OG, Olaniyi BH, Jegede OO, Ayoola MA, Bashiru MI (2015) Chemical compositions and source identification of particulate matter $\left(\mathrm{PM}_{2.5}\right.$ and $\mathrm{PM}_{2.5-10}$ ) from a scrap iron and steel smelting industry along the Ife-Ibadan highway, Nigeria. Atmos Pollut Res 6:107-119. https:// doi.org/10.5094/APR.2015.013

Öblad M, Selin E (1985) Measurements of $\mathrm{Br} / \mathrm{Pb}$ ratios in airborne particles from car exhaust. Phys Scr 32:462-468. https://doi.org/10. 1088/0031-8949/32/4/036

Papp S, Kümmel R (1992) Environmental chemistry (in Hungarian). Tankönyvkiadó, Budapest

Pekey H, Pekey B, Arslanbas D, Bozkurt Z, Dogan G, Tuncel G (2015) Source identification of volatile organic compounds and particulate matters in an urban and industrial areas of Turkey. Ekoloji 24:1-9. https://doi.org/10.5053/ekoloji.2015.941

Petkova EP, Jack DW, Volavka-Close NH, Kinney PL (2013) Particulate matter pollution in African cities. Air Qual Atmos Health 6:603614. https://doi.org/10.1007/s11869-013-0199-6

Piketh SJ, Swap RJ, Maenhaut W, Annegarn HJ, Formenti P (2002) Chemical evidence of long-range atmospheric transport over southern Africa. J Geophys Res 107(D24, 4871):1-7. https://doi.org/10. 1029/2002JD002056

Pio CA, Nunes TV, Borrego CA, Martins JG (1989) Assessment of air pollution sources in an industrial atmosphere using principal component and multilinear regression analysis. Sci Total Environ 80: 279-292. https://doi.org/10.1016/0048-9697(89)90082-X

Pósfai M, Simonics R, Li J, Hobbs PV, Buseck PR (2003) Individual aerosol particles from biomass burning in southern Africa: 1 . Compositions and size distributions of carbonaceous particles. J Geophys Res Atmos 108(D13, 8483):1-13. https://doi.org/10. 1029/2002JD002291

Remoundaki E, Papayannis A, Kassomenos P, Mantas E, Kokkalis P, Tsezos M (2013) Influence of Saharan dust transport events on $\mathrm{PM}_{2.5}$ concentrations and composition over Athens. Water Air Soil Pollut 224:1373. https://doi.org/10.1007/s11270-012-1373-4 
Seinfeld JH, Pandis SN (2016) Atmospheric chemistry and physics from air pollution to climate change, 3rd edn. Wiley-Interscience, Malden

Talebi SM (1998) Determination of lead associated with airborne particulate matter by flame atomic absorption and wave-length dispersive x-ray fluorescence spectrometry. Int J Environ Anal Chem 72:1-9. https://doi.org/10.1080/03067319808032640

Tsai JH, Chang KL, Lin JJ, Lin YH, Chiang HL (2005) Mass-size distribution of particulate sulfate, nitrate and ammonium matter nonattainment region in southern Taiwan. J Air Waste Manage Assoc 55:502-509. https://doi.org/10.1080/10473289.2005. 10464640

US EPA - United States Environmental Protection Agency (2020) https:// www.epa.gov/pmcourse/patient-exposure-and-air-quality-index. Accessed 8 May 2020

Van Grieken RE, Markowicz AA (2001) Handbook of X-ray spectrometry, 2nd (Revised and expanded) edn. CRC Press, Boca Raton

Wang YF, Huang KL, Li TC, Mi HH, Luo JH, Tsai PJ (2003) Emissions of fuel metals content from a diesel vehicle engine. Atmos Environ 37:4637-4643. https://doi.org/10.1016/j.atmosenv.2003.07.007
WHO Regional Office for Europe, European Centre for Environment and Health (2020) AirQ+: software tool for health risk assessment of air pollution Bonn. WHO Regional Office for Europe, Germany http:// www.euro.who.int/en/health-topics/environment-and-health/airquality/activities/airq-software-tool-for-health-risk-assessment-ofair-pollution. (Accessed: 15 April 2020)

Zelenyuk A, Cai Y, Chieffo L, Imre D (2005) High precision density measurements of single particles: the density of metastable phases. Aerosol Sci Technol 39:972-968. https://doi.org/10.1080/ 02786820500380206

Zhang JZ, Zhou XH, Wang Z, Yang LX, Wang J, Wang WX (2018) Trace elements in $\mathrm{PM}_{2.5}$ in Shandong Province: source identification and health risk assessment. Sci Total Environ 621:558-577. https://doi. org/10.1016/j.scitotenv.2017.11.292

Publisher's note Springer Nature remains neutral with regard to jurisdictional claims in published maps and institutional affiliations. 